\title{
Efectos del hormigón reforzado con fibra de acero en la ductibilidad estructural
}

\section{The effects of steel fibre reinforced concrete on system ductility}

\author{
M.Y. Kaltakci ${ }^{*}$, M. H. Arslan*, U. S. Yilmaz
}

Recepción/Received: 20-IV-2005

Aceptación/Accepted: 31-V-2006

\section{RESUMEN}

El hormigón reforzado con fibra de acero se emplea actualmente tanto en obra como en los trabajos experimentales para estudiar la resistencia mecánica y ductilidad del hormigón. El estado de confinamiento pasivo producido por la fibra retrasa la fisuración y aumenta la ductilidad. El presente trabajo es de índole tanto experimental como analítica. En primer lugar, en la parte experimental se aplica una fuerza axial a 16 probetas prismáticas ( $160 \times 160 \times 840$ $\mathrm{mm}$ ) de hormigón reforzado con fibra de acero para determinar su comportamiento, obteniéndose las curvas de fuerza axial-deformación unitaria correspondientes a partir de los resultados observados. A partir de una evaluación de dichos resultados experimentales, se determina el efecto que ejercen las fibras de acero sobre la ductilidad de las probetas de hormigón armado. En la segunda parte del trabajo, se realiza un estudio analítico para determinar el posible aumento de la ductilidad de un sistema estructural al incorporar fibras de acero al hormigón empleado en su construcción. Se desarrollan modelos analíticos para 16 estructuras de hormigón armado de dos plantas y un solo vano. Las características de los pilares de dichas estructuras son idénticas a las de las probetas ensayadas en el estudio experimental. Se efectúan análisis estáticos no lineales (análisis "pushover") de todas las estructuras, a fin de obtener las curvas de fuerza-desplazamiento y determinar los efectos de las fibras de acero sobre la ductilidad de pilares de hormigón armado.

Palabras clave: composite, hormigón, deformación, resistencia a la compresión, refuerzo de fibras.

\section{SUMMARY}

Steel fibre-reinforced concrete is being used extensively today in both field applications and experimental studies on concrete strength and ductility. The state of passive confinement generated by the fibre delays cracking and enhances ductility. The present paper reports on both experimental and analytical studies. In the former, a series of 16 steel-fibre reinforced concrete prismatic specimens were subjected to axial loads and the respective axial load-unit strain diagrams were subsequently plotted to determine the effect of steel fibres on reinforced concrete column ductility. Secondly, an analytical study was run to determine the additional ductility accruing to a frame system when steel fibres are included in the concrete. Analytical models were generated for 16 two-storey, single-span reinforced concrete frames. The columns in these frames were designed to the same characteristics as the specimens used in the experimental tests. Non-linear static (pushover) analyses were performed for each frame to obtain load-displacement curves and determine the effect of steel fibres on reinforced concrete column ductility.

Keywords: composite, concrete, deformation, compressive strength, fibre-reinforced.

\footnotetext{
(*) Universidad de Selcuk, Konya (Turquía).
} 
Símbolos empleados

\begin{tabular}{|ll|}
\hline$\mu \varepsilon$ & ductilidad del material \\
\hline$\mu \delta$ & ductilidad del sistema \\
\hline$\varepsilon_{y}$ & deformación en el límite elástico \\
\hline$\varepsilon_{u}$ & deformación de rotura \\
\hline$\varepsilon^{\prime}{ }_{u} / \varepsilon^{\prime}{ }_{s u}$ & $\begin{array}{l}\text { deformación de rotura de un elemento no reforzado } \\
\end{array}$ \\
\hline$\delta_{u}$ & reforzado con fibra \\
\hline$\delta_{y}$ & desplazamiento de rotura \\
\hline $\mathrm{f}_{\mathrm{c}}$ & resistencia a la compresión del hormigón \\
& (en probetascilíndricas) \\
\hline $\mathrm{f}_{\mathrm{ys}}$ & límite elástico de la armadura \\
\hline $\mathrm{h}$ & altura del pilar \\
\hline$\varepsilon$ & deformación longitudinal unitaria de los pilares \\
\hline $\mathrm{N}_{\mathrm{o}}$ & capacidad resistente \\
\hline $\mathrm{N}_{\mathrm{e}}$ & capacidad resistente experimental \\
\hline $\mathrm{A}_{\mathrm{S}}$ & sección de la armadura longitudinal \\
\hline $\mathrm{A}_{\mathrm{c}}$ & sección del hormigón \\
\hline $\mathrm{K}$ & relación entre la fuerza axial y la teórica \\
\hline $\mathrm{R}$ & factor de modificación de la respuesta estructural \\
\hline $\mathrm{B}$ & coeficiente de seguridad \\
\hline $\mathrm{LVDT}$ & transformador diferencial variable lineal \\
\hline
\end{tabular}

\section{INTRODUCCIÓN}

El hormigón reforzado con fibra de acero, que se obtiene al incorporar distintas cuantías de alambres de acero con características especiales al hormigón en masa, se emplea para mejorar el comportamiento del material tradicional mediante la corrección de muchos de sus defectos. Al estudiar el hormigón reforzado con fibra, distintos autores (1-5) han demostrado que la incorporación de ésta mejora muchas de las propiedades estructurales de aquél, entre ellas la tenacidad del hormigón y su resistencia a la flexión, tracción, colisión, fatiga y choque térmico. La mejora de las prestaciones del hormigón armado pasa por la reducción de su fragilidad. Las investigaciones más recientes en este sentido (6-8) se centran en el efecto que ejerce la fibra de acero sobre la resistencia a la fisuración y a la abrasión del hormigón armado.

La fibra de acero incide en dicho comportamiento de distintas maneras:

- Evita la fisuración.

- Limita el desarrollo de la fisuración.

- Aumenta la resistencia mecánica y la ductilidad del hormigón.

Sobre todo en los elementos que soportan cargas axiales, la fibra limita la fisuración de hormigón al producirse un estado de confinamiento dentro del elemento en cuestión. Con ello se mejora la ductilidad del elemento y,
Notation

\begin{tabular}{|ll|}
\hline$\mu \varepsilon$ & material ductility \\
\hline$\mu \delta$ & system ductility \\
\hline$\varepsilon_{y}$ & yield strain \\
\hline$\varepsilon_{u}$ & ultimate strain \\
\hline$\varepsilon^{{ }^{\prime}}{ }_{u} / \varepsilon^{\prime}{ }_{s u}$ & $\begin{array}{l}\text { ultimate strain of a non-fibre reinforced / fibre } \\
\text { reinforced member }\end{array}$ \\
\hline$\delta_{u}$ & ultimate displacement \\
\hline$\delta_{y}$ & yield displacement \\
\hline$f_{c}$ & concrete compressive strength (for cylindrical \\
\hline$f_{y s}$ & specimen) \\
\hline$h$ & yield strength of reinforcement \\
\hline$\varepsilon$ & column height \\
\hline$N_{o}$ & longitudinal unit strain in columns \\
\hline$N_{e}$ & carrying capacity \\
\hline$A_{s}$ & experimental load carrying capacity \\
\hline$A_{c}$ & cross-sectional area of longitudinal reinforcement \\
\hline$K$ & cross-sectional area of concrete \\
\hline$R$ & ratio of axial to theoretical load \\
\hline$B$ & behaviour factor, structural response factor, \\
\hline$L V T$ & response modification coefficient \\
\hline
\end{tabular}

\section{INTRODUCTION}

Steel fibre reinforced concrete, obtained by adding various ratios of steel wires with specific characteristics to plain concrete, is used to enhance the performance of the traditional material by strengthening many of its weak points. Research on fibre-reinforced concrete by different authors (1-5) has shown that the inclusion of such fibres improves many structural properties, such as toughness, flexural, tensile and impact strength, and fatigue and thermal shock resistance. Decreasing reinforced concrete brittleness may be the most effective way to improve its performance. Current research on the subject (6-8) focuses on the effect of steel fibres on $R C$ performance in the context of cracking and abrasion.

Steel fibre may affect concrete behaviour in a number of ways:

\section{- Preventing cracking.}

- Confining cracking.

- Increasing concrete strength and ductility.

Particularly in axially loaded members, fibre limits concrete cracking by generating a state of confinement in the member. This enhances member -and consequently system-ductility, as borne out by the findings reported 
por consiguiente, del sistema, observación ésta que han corroborado los trabajos de Shah y Rangan (9). La ductilidad puede considerarse la capacidad que tiene la estructura de soportar deformaciones plásticas importantes sin que disminuya su resistencia mecánica. Existen en la bibliografía técnica numerosos trabajos que versan sobre la ductilidad, a nivel del material, de la sección, del elemento y del sistema (10-11). La ductilidad del material y del sistema se representa en las curvas de fuerza-desplazamiento reproducidas en las Figuras 1a y $1 b$, respectivamente. En el presente trabajo se han adoptado las siguientes expresiones para definir la ductilidad del material:

$$
\mu_{\varepsilon}=\frac{\varepsilon_{\mathrm{u}}}{\varepsilon_{\mathrm{y}}}
$$

y del sistema:

$$
\mu_{\delta}=\frac{\delta_{u}}{\delta_{y}}
$$

Se observará que en las estructuras de hormigón armado la ductilidad del sistema se define en función de la deformación. Así, puede representarse como la relación entre el desplazamiento lateral en el momento de la rotura y el desplazamiento en el momento en que el material empieza a alcanzar su límite elástico. Hay en la bibliografía varios criterios para definir el desplazamiento en el límite elástico y en el punto de rotura. Según el más extendido, el desplazamiento en el límite elástico equivale al que corresponde al $75 \%$ de la carga de rotura $\left(\mathrm{F}_{75}, \delta_{75}\right)$, considerándose que el sistema falla al alcanzar el $85 \%$ de dicha carga de rotura $\left(\mathrm{F}_{85}\right.$, $\left.\delta_{85}\right)(12)$ (Figura 2).

La ductilidad del sistema, el objeto del presente trabajo, es un aspecto esencial a la hora de determinar el factor de respuesta estructural, $\mathrm{R}$, uno de los parámetros más importantes de la ingeniería estructural $\left(\mu_{\delta} \approx \mathrm{R}\right)$. La normativa vigente de edificación en zonas sísmicas incorpora el

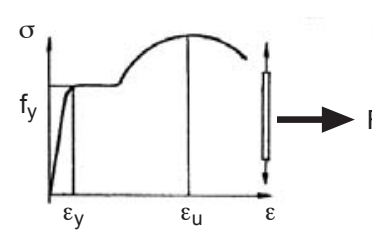

(a)

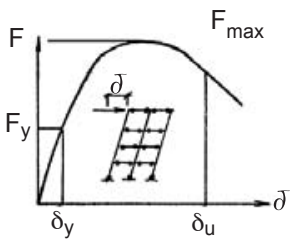

(b)
Figura 1. Curvas de fuerza-desplazamiento del material y del sistema.

Figure 1. Material and system load-displacement curves. by Shah and Rangan (9). Ductility may be regarded to be the ability of a structure to support substantial plastic strain with no strength loss. Material, cross-section, member and system ductility have all been addressed in the literature (10-11). Material and system ductility are respectively represented in the load-displacement curves in Figures 1a and 1b. Here, the expression used for material ductility is:

and for system ductility:

Note that in reinforced concrete structures system ductility is given in terms of strain. System ductility may be expressed, then, as the ratio of ultimate lateral displacement to displacement when the material begins to yield. Various criteria for defining yield displacement and failure can be found in the literature. According to the most widely accepted definition yield displacement is equal to the displacement corresponding to $75 \%$ of the ultimate load $\left(F_{75}, \delta_{75}\right)$ and system failure is reached at $85 \%$ of the ultimate load $\left(F_{85}, \delta_{85}\right)(12)$ (Figure 2).

System ductility, examined in this study, is instrumental in determining the behaviour factor (also known as the structural response factor or response modification coefficient), $R$, one of the most important parameters in structural engineering $\left(\mu_{\delta} \approx R\right)$. Modern construction

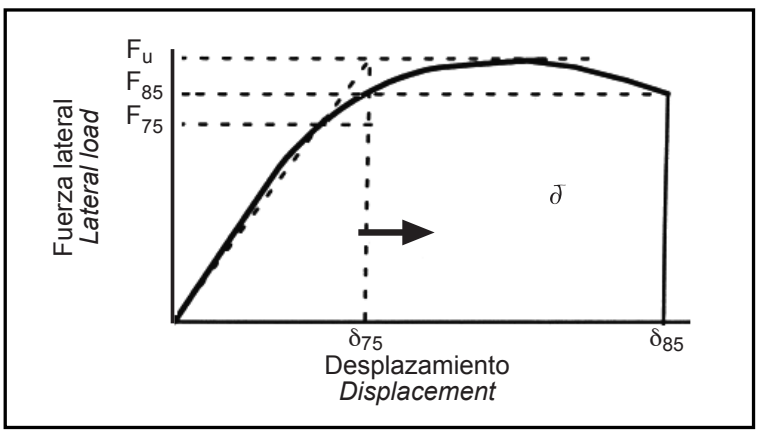

Figura 2. Criterios relacionados con las curvas de fuerzadesplazamiento (12).

Figure 2. Load-displacement curve criteria (12). 
concepto de que si son lo suficientemente dúctiles, las estructuras pueden absorber parte del movimiento generado por los seísmos, incluso los de mayor envergadura. En una estructura dúctil, la energía inelástica puede liberarse de manera algo controlada, manteniéndose intactas la integridad y la estabilidad del sistema estructural. Esto conlleva una reducción considerable de la fuerza sísmica de cálculo, por lo que, en general, el proyecto de estructuras dúctiles implica costes más bajos. En la normativa sísmica en vigor en Turquía (13) y en otros países (14-15), la aplicación del factor R se justifica partiendo de la base de que las fuerzas sísmicas elásticas son menores en las estructuras que presentan un comportamiento dúctil. Recientemente, sobre todo, los estudios que tratan del cálculo de la ductilidad del sistema $\left(\mu_{\delta}\right)$ (16-17) han demostrado ser de enorme interés en la determinación de dicho factor de modificación de la respuesta elástica, $R$, un concepto clave en la ingeniería sísmica que se recoge en la normativa del mundo entero.

El presente trabajo consta de dos partes. En la primera, se someten a fuerzas axiales una serie de probetas con cuantías variables de fibra de acero, constatando las diferencias entre los valores de deformación. Posteriormente, partiendo de las curvas de fuerza-deformación unitaria obtenidas para el hormigón con distintas cuantías de fibra, se calcula el comportamiento de una estructura típica sometida a fuerzas progresivamente mayores, y se establecen las relaciones causa-efecto mediante el estudio de las curvas de fuerza-desplazamiento correspondientes a cada cuantía de fibra. Más concretamente, en este estudio analítico se obtienen las curvas de fuerzadesplazamiento mediante el análisis estático no lineal (análisis "pushover") de 16 estructuras de hormigón armado de dos plantas y un solo vano, cuyos pilares presentan las mismas características que las probetas. Según se ha indicado, el método empleado en esta fase del estudio es el del análisis estático no lineal. El objetivo del mismo es el de evaluar el comportamiento previsto de un sistema estructural mediante la estimación de la resistencia mecánica y la deformación demandadas en el supuesto de fuerzas sísmicas y la comparación de las mismas a los valores de referencia para los distintos niveles de seguridad exigidos. El análisis estático no lineal permite obtener información sobre muchas características de la respuesta estructural que no puede estimarse con los análisis estáticos y dinámicos convencionales.

\section{PROGRAMA EXPERIMENTAL}

\subsection{Plan de trabajo experimental}

El programa experimental ha constado de la realización de ensayos de baja carga axial en pilares de hormigón reforzado con fibra de acero. La sección de las probetas era de 160 x $160 \mathrm{~mm}$ y la altura de $840 \mathrm{~mm}$. Las variables codes for seismic areas incorporate the idea that if sufficiently ductile, structures can accommodate a certain amount of the damage caused by major earthquakes. In a ductile structure, inelastic energy can be released in a more or less controlled fashion without jeopardizing the integrity or stability of the structural system. As a result, the design seismic load can be reduced drastically, making ductile design generally economical. In the seismic regulations in place in Turkey (13) and other countries (14-15), introduction of the $R$ factor is justified by the assumption that elastic seismic loads are smaller in structures exhibiting ductile behaviour. Particularly in recent years, studies calculating frame ductility $\left(\mu_{\delta}\right)(16-17)$ have proven to be of great importance for determining behaviour factor $R$, a key concept in earthquake engineering that is addressed in seismic legislation the world over.

This study was divided into two parts. In the first, experiments were conducted to establish the differences in the strain recorded when $R C$ columns with varying steel fibre ratios were subjected to axial loading. Subsequently, based on the normal load-unit strain curves obtained for material with various amounts of fibre, the behaviour of a sample frame under increasing loads was calculated and cause-effect relationships were drawn by examining the load-displacement curves for each ratio of fibre. More specifically, in this analytical study load-displacement curves were obtained by conducting non-linear static analysis (pushover analysis) of 16 two-storey, single span reinforced concrete frames with columns of the same characteristics as the test specimens. Pushover analysis was chosen for this stage of the study. The purpose of pushover analysis is to evaluate the expected performance of a structural system by estimating its strength and strain demands under design seismic loads and comparing these demands to reference values for different performance levels. Pushover analysis can provide information on many response characteristics that cannot be obtained from conventional static or dynamic analysis.

\section{EXPERIMENTAL}

\subsection{Protocol}

The experimental programme was designed to test steel fibre-reinforced concrete columns under axial loads. The specimens measured $160 \times 160 \mathrm{~mm}$ by $840 \mathrm{~mm}$ high. The variables studied were the ratio of fibre in the 
Tabla 1 / Table 1

Probetas

Test Specimens

\begin{tabular}{|c|c|c|c|c|c|c|c|c|}
\hline \multirow[t]{2}{*}{$\begin{array}{l}\text { No de probeta } \\
\text { Specimen No }\end{array}$} & \multirow[t]{2}{*}{$\begin{array}{c}\text { Resistencia } \\
\text { a la compresión } \\
\text { del hormigón } \\
\text { Concrete compressive } \\
\text { strength } \\
\text { fc (MPa) }\end{array}$} & \multicolumn{2}{|c|}{$\begin{array}{l}\text { Armadura } \\
\text { longitudinal } \\
\text { Longitudinal } \\
\text { reinforcement }\end{array}$} & \multicolumn{2}{|c|}{$\begin{array}{c}\text { Armadura } \\
\text { transversal } \\
\text { Transverse } \\
\text { reinforcement }\end{array}$} & \multicolumn{2}{|c|}{$\begin{array}{c}\text { Armadura transversal } \\
\text { de confinamiento } \\
\text { Transverse confinement } \\
\text { reinforcement }\end{array}$} & \multirow[t]{2}{*}{$\begin{array}{c}\text { Cuantía de fibra } \\
\text { de acero } \\
\left(\mathrm{kg} / \mathrm{m}^{3}\right) \\
\text { Steel fibre ratio } \\
\left(\mathrm{kg} / \mathrm{m}^{3}\right) \\
\end{array}$} \\
\hline & & $\begin{array}{l}\text { Diámetro }(\mathrm{mm}) \\
\text { Diameter }(\mathrm{mm})\end{array}$ & $\begin{array}{c}\text { fy } \\
\text { (MPa) }\end{array}$ & $\begin{array}{l}\text { Diámetro ( } \\
\text { Diameter ( }\end{array}$ & $\begin{array}{c}\text { fy } \\
\text { (MPa) }\end{array}$ & NC* & C** & \\
\hline $\mathrm{A} 1$ & 20.35 & 11.76 & 548.6 & 7.74 & 440 & ----- & $\sqrt{ }$ & 0 \\
\hline B1 & 19.80 & 11.76 & 548.6 & 8.1 & 440 & $\sqrt{ }$ & ----- & 0 \\
\hline $\mathrm{C} 1$ & 20.16 & 11.76 & 436.9 & 7.74 & 268 & ----- & $\sqrt{ }$ & 0 \\
\hline D1 & 20.05 & 11.76 & 436.9 & 8.1 & 268 & $\sqrt{ }$ & ----- & 0 \\
\hline $\mathrm{A} 2$ & 20.27 & 11.76 & 548.6 & 7.74 & 440 & ----- & $\sqrt{ }$ & 20 \\
\hline B2 & 19.85 & 11.76 & 548.6 & 8.1 & 440 & $\sqrt{ }$ & ----- & 20 \\
\hline $\mathrm{C} 2$ & 20.13 & 11.76 & 436.9 & 7.74 & 268 & ----- & $\sqrt{ }$ & 20 \\
\hline $\mathrm{D} 2$ & 20.00 & 11.76 & 436.9 & 8.1 & 268 & $\sqrt{ }$ & ----- & 20 \\
\hline $\mathrm{A} 3$ & 20.36 & 11.76 & 548.6 & 7.74 & 440 & ----- & $\sqrt{ }$ & 40 \\
\hline B3 & 19.91 & 11.76 & 548.6 & 8.1 & 440 & $\sqrt{ }$ & ----- & 40 \\
\hline $\mathrm{C} 3$ & 20.15 & 11.76 & 436.9 & 7.74 & 268 & ----- & $\sqrt{ }$ & 40 \\
\hline D3 & 20.10 & 11.76 & 436.9 & 8.1 & 268 & $\sqrt{ }$ & ----- & 40 \\
\hline A4 & 19.87 & 11.76 & 548.6 & 7.74 & 440 & ----- & $\sqrt{ }$ & 60 \\
\hline B4 & 20.03 & 11.76 & 548.6 & 8.1 & 440 & $\sqrt{ }$ & ----- & 60 \\
\hline $\mathrm{C} 4$ & 21.12 & 11.76 & 436.9 & 7.74 & 268 & ----- & $\sqrt{ }$ & 60 \\
\hline D4 & 19.50 & 11.76 & 436.9 & 8.1 & 268 & $\sqrt{ }$ & ----- & 60 \\
\hline
\end{tabular}

* Sin confinamiento / Non-confined.

** Con confinamiento / Confined.

estudiadas eran la cuantía de fibra incorporada al hormigón $\left(\mathrm{kg} / \mathrm{cm}^{3}\right)$, la carga de rotura de la armadura transversal y longitudinal y la presencia o ausencia de armadura de confinamiento. Se agruparon las 16 probetas estudiadas en cuatro series $(1,2,3$ y 4$)$, que se distinguían entre sí por las cuantías de fibra de acero que llevaban: $0,0 \mathrm{~kg} / \mathrm{m}^{3}, 20 \mathrm{~kg} / \mathrm{m}^{3}, 40 \mathrm{~kg} / \mathrm{m}^{3}$ y $60 \mathrm{~kg} / \mathrm{m}^{3}$. Cada serie se dividía, a su vez, en cuatro subgrupos, A, B, C y $D$ que se diferenciaban en el límite elástico de la armadura empleada y en la presencia o ausencia de armadura de confinamiento (Tabla 1 ).

\subsection{Materiales}

En todas las probetas se emplearon fibras de acero de diámetro 0,75 y una relación longitud/diámetro de 80 . La geometría de las probetas se describe en la Tabla 2. La relación agua/cemento del hormigón era de 0,49 , con una dosificación de $350 \mathrm{~kg} / \mathrm{m}^{3}$ para obtener un material de resistencia a la compresión de $20 \mathrm{MPa}$. De acuerdo con la instrucción sísmica de Turquía de 1998 (TEC-98) (13), no podrá emplearse hormigón con una resistencia mecánica menor de $20 \mathrm{MPa}$ en edificios que se construyen en zonas sísmicas. La Tabla 1 también indica la resistencia mecánica observada al someter a ensayos de compresión probetas cilíndricas y normalizadas de 150 × 300 mm, fabricadas concrete $\left(\mathrm{kg} / \mathrm{m}^{3}\right)$, transverse/ longitudinal reinforcement yield strength and the existence or otherwise of confinement reinforcement. The 16 columns tested were divided into four groups (1, 2, 3 and 4), each with a different steel fibre content, namely: $0.0 \mathrm{~kg} / \mathrm{m}^{3}, 20 \mathrm{~kg} / \mathrm{m}^{3}, 40$ $\mathrm{kg} / \mathrm{m}^{3}$ and $60 \mathrm{~kg} / \mathrm{m}^{3}$. Each group was in turn divided into four sub-groups, $A, B, C$ and $D$, which differed in the yield strength of the reinforcing steel used in the columns and the presence or absence of confinement (Table 1).

\subsection{Test Material}

Steel fibres with a diameter of 0.75 and an aspect (length/diameter) ratio of 80 were used in all specimens. Fibre geometry is given in Table 2. The water/cement ratio of the concrete was 0.49 and its dosage $350 \mathrm{~kg} / \mathrm{m}^{3}$. The aim was to make concrete with a compressive strength of $20 \mathrm{MPa}$. Pursuant to the Turkish Earthquake Code-1998 (TEC-98) (13), concrete with a strength of less than $20 \mathrm{MPa}$ may not be used in buildings to be erected in seismic zones. Table 1 also gives the mechanical strength of concrete found by compression testing standard, non-reinforced cylindrical specimens measuring $150 \times 300 \mathrm{~mm}$. Three specimens in each sub-group were 
con hormigón en masa. Se utilizaron tres probetas de cada subgrupo para evaluar la resistencia a la compresión del hormigón, de acuerdo con lo previsto en la instrucción TBC-500-2000 (18), según la que de cada amasada, deberá ensayarse una serie de al menos tres probetas.

\subsection{Preparación y almacenamiento de las probetas}

Una vez preparadas las jaulas, se colocaron con cuidado en los moldes. Las probetas se hormigonaron en posición vertical. Los moldes se llenaron en dos tongadas, compactando el hormigón de cada una con un vibrador de aguja. Las probetas se desmoldaron a las 24 horas, guardándose en arpillera húmeda durante los 20 días siguientes. A partir de ese momento, se curaron a temperatura ambiente hasta el día 28. Puede observarse la disposición de la armadura de las probetas en los esquemas de la Figura 3.

\subsection{Montaje del ensayo y procedimientos seguidos}

Todos los ensayos de fuerza axial se realizaron en el Laboratorio de Edificación y Materiales del Departamento de Ingeniería de Obra Pública del la Universidad de Selcuk. Se aplicaron las fuerzas a razón de 1 tonelada/seg, con control servoeléctrico. Mediante una gruesa placa de acero (20 $\mathrm{mm}$ ) colocada entre la probeta y la prensa se logró una distribución uniforme de la carga en toda la sección de aquélla. La cara inferior de la prisma se apoyaba en una plataforma rígida e inmóvil montada en el bastidor de la máquina de ensayos. La célula de carga recogía y registraba los datos de presión. Se instalaron doce transformadores diferenciales variables lineales (LVDT) en diferentes puntos para medir y registrar los desplazamientos verticales y horizontales a intervalos predeterminados dentro de cada incremento de carga hasta que se rompía la probeta. El montaje del ensayo se aprecia en la fotografía de la Figura 4, que también muestra la disposición de los LVDT.

Tabla 2 / Table 2

Geometría de las fibras

Fibre geometry

\begin{tabular}{|c|c|c|c|c|}
\hline $\begin{array}{l}\text { Tipo } \\
\text { Type }\end{array}$ & $\begin{array}{l}\text { Forma } \\
\text { Shape }\end{array}$ & $\begin{array}{c}\text { Longitud } \\
\text { Length } \\
(\mathrm{mm})\end{array}$ & $\begin{array}{c}\text { Sección } \\
\text { Cross Section }\end{array}$ & $\begin{array}{c}\text { Diámetro } \\
\text { Diameter } \\
(\mathbf{m m})\end{array}$ \\
\hline $\begin{array}{l}\text { De extremos } \\
\text { conformados }\end{array}$ & 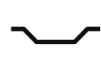 & 60 & Circular & 0.75 \\
\hline Hooked & & 60 & Circular & 0.75 \\
\hline
\end{tabular}

used to evaluate concrete compressive strength, to meet TBC-500-2000 (18) requirements, whereby at least one series of three test specimens must be taken from each batch.

\subsection{Test specimen preparation and storage}

The reinforcement cages prepared were carefully placed in moulds. Column specimens were cast in a vertical position. A needle vibrator was used to consolidate the concrete after each of the two lifts needed to fill the moulds. The specimens were removed from the forms one day after casting and stored in moist burlap for a further 20 days. Thereafter they were kept at room temperature until day 28. Test specimen reinforcement geometry is shown in Figure 3.

\subsection{Test set-up and procedure}

All specimens were tested under axial loads at the Selcuk University Civil Engineering Department's Building and Materials Laboratory. Axial loads were applied to specimens at a rate of 1 tonne/sec, controlled by an electrical servomotor. Load uniformity across the entire cross-section of columns was ensured by a thick $(20-\mathrm{mm})$ steel plate. The bottom of the column rested on a rigid immobile platform connected to the frame. Data were logged by the load cell. Twelve linear variable differential transformers (LVDT) positioned at pre-defined points were used to measure and record vertical and horizontal displacements at specific intervals in each load step until the specimen failed. A photograph of the test set-up and sketch of the LVDT arrangement are shown in Figure 4.

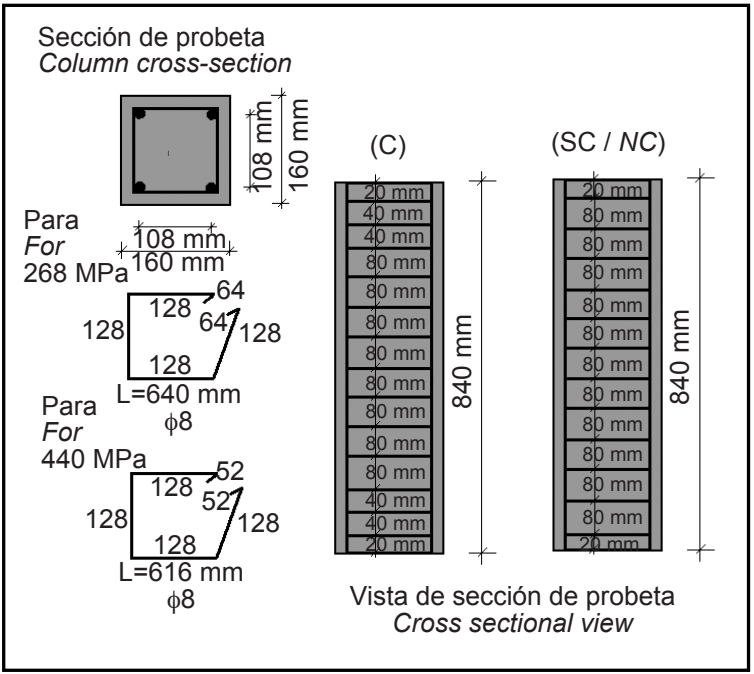

Figura 3. Detalle de la armadura de las probetas. Figure 3. Specimen reinforcement detailing. 


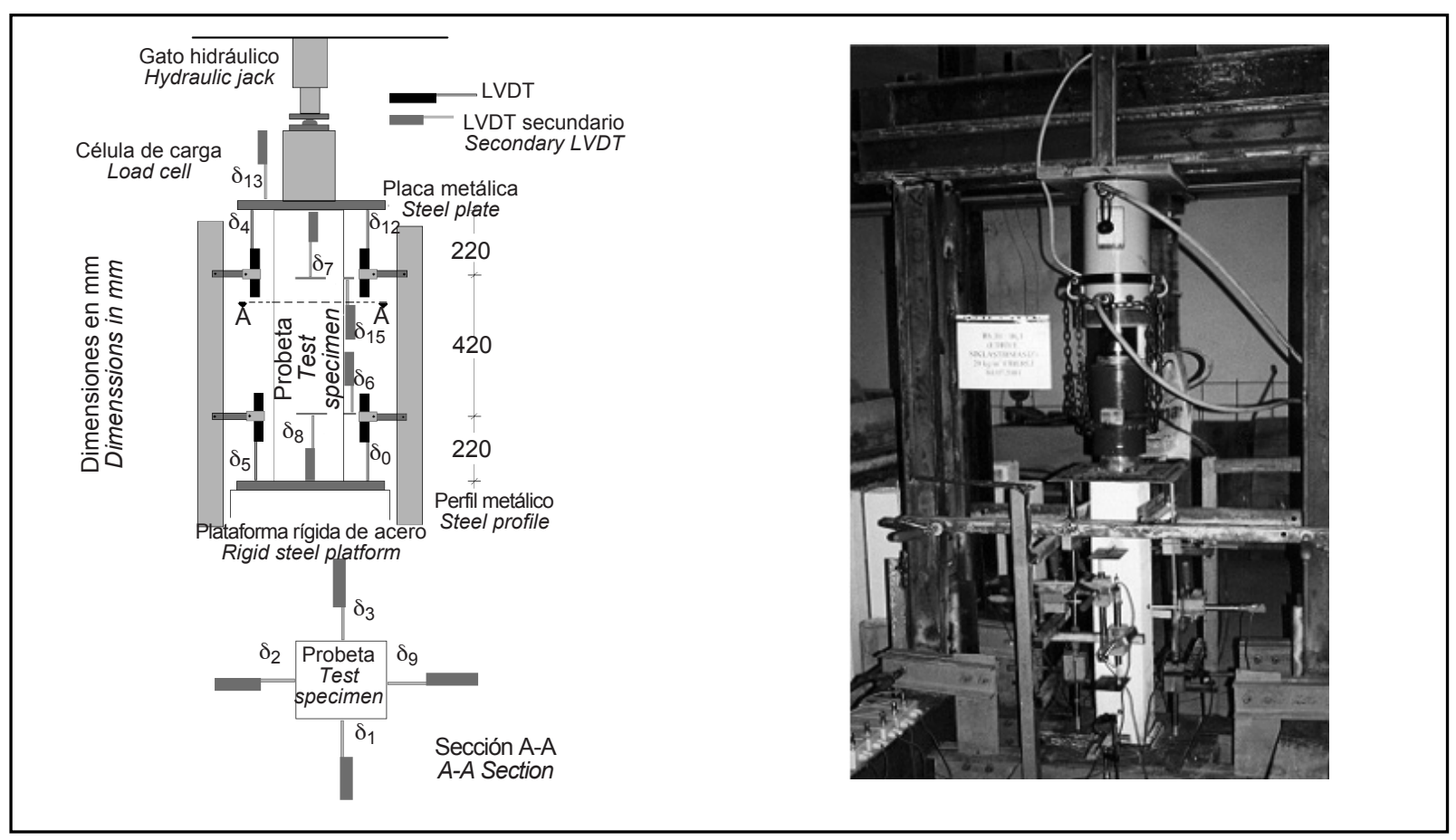

Figura 4. Disposición de los LVDT y foto del montaje de los ensayos.

Figure 4. LVDT positioning and photograph of test set-up.

\subsection{Evaluación de los resultados de los ensayos}

Se calculó la deformación longitudinal unitaria total, $\varepsilon$, a partir de la expresión (3), es decir, dividiendo entre la altura de la probeta la suma del promedio de las variaciones de su longitud registradas por los LVDT $\delta_{4}$ y $\delta_{5}$, por una parte, y por los LVDT $\delta_{12}$ y $\delta_{0}$, por otra. (Aunque la plataforma en que se apoyaban las caras inferiores de las probetas era rígida, se colocaron en ella los LVDT $\delta_{4}$ y $\delta_{5}$, a fin de detectar posibles desplazamientos producidos durante el experimento.) Por lo tanto, los resultados del experimento se presentan en una gráfica en que se relaciona la deformación unitaria con la fuerza axial.

\subsection{Evaluation of test results}

Total longitudinal unit strain, $\varepsilon$, was found as shown in Formula 3, i.e., by dividing the sum of the mean variations in column length recorded by LVDT $\delta_{4}$ and $\delta_{12}$ on the one hand and LVDT $\delta_{0}$ and $\delta_{5}$ on the other, by the column height. (Although the platform supporting the bottom of the column was rigid, LVDT $\delta_{0}$ and $\delta_{5}$ were positioned there to record any displacements possibly taking place during the experiment.) Consequently, the results of the experiment were presented as a graph plotting unit strain versus axial load.

$$
\varepsilon=\frac{\left(\delta_{4}-\delta_{5}\right)+\left(\delta_{12}-\delta_{0}\right)}{2 h}
$$

Todos los demás instrumentos se colocaron de forma que controlaran la estabilidad lateral de las probetas. En la Figura 5 se reproducen, para cada serie y subgrupo, las curvas que muestran la deformación en función de la fuerza axial. La similitud del brazo ascendente de la curva en todos los casos indica un comportamiento semejante de todas las probetas. Sometidas a fuerza axial, alcanzaban su capacidad resistente máxima cuando el hormigón llegaba a su resistencia a la compresión y el acero de las armaduras a su límite elástico. La expresión 4 define la carga teórica que puede soportar un elemento de hormigón armado sometido a una fuerza axial. Los
All the other instruments were positioned to monitor the lateral stability of the specimens. The axial load - unit strain graphs plotted for each group and sub-group are shown in Figure 5. The similarity in the upward arm on all the graphs is an indication of like behaviour in all specimens. Under axial loads, the columns attained their load-bearing capacities when the concrete reached its compressive strength and the reinforcing steel its yield strength. Equation 4 defines the theoretical load that can be carried by an axially loaded reinforced concrete member. The reinforcement and concrete capacities are respectively limited by steel yield strength $\left(f_{y} A_{s}\right)$ and 


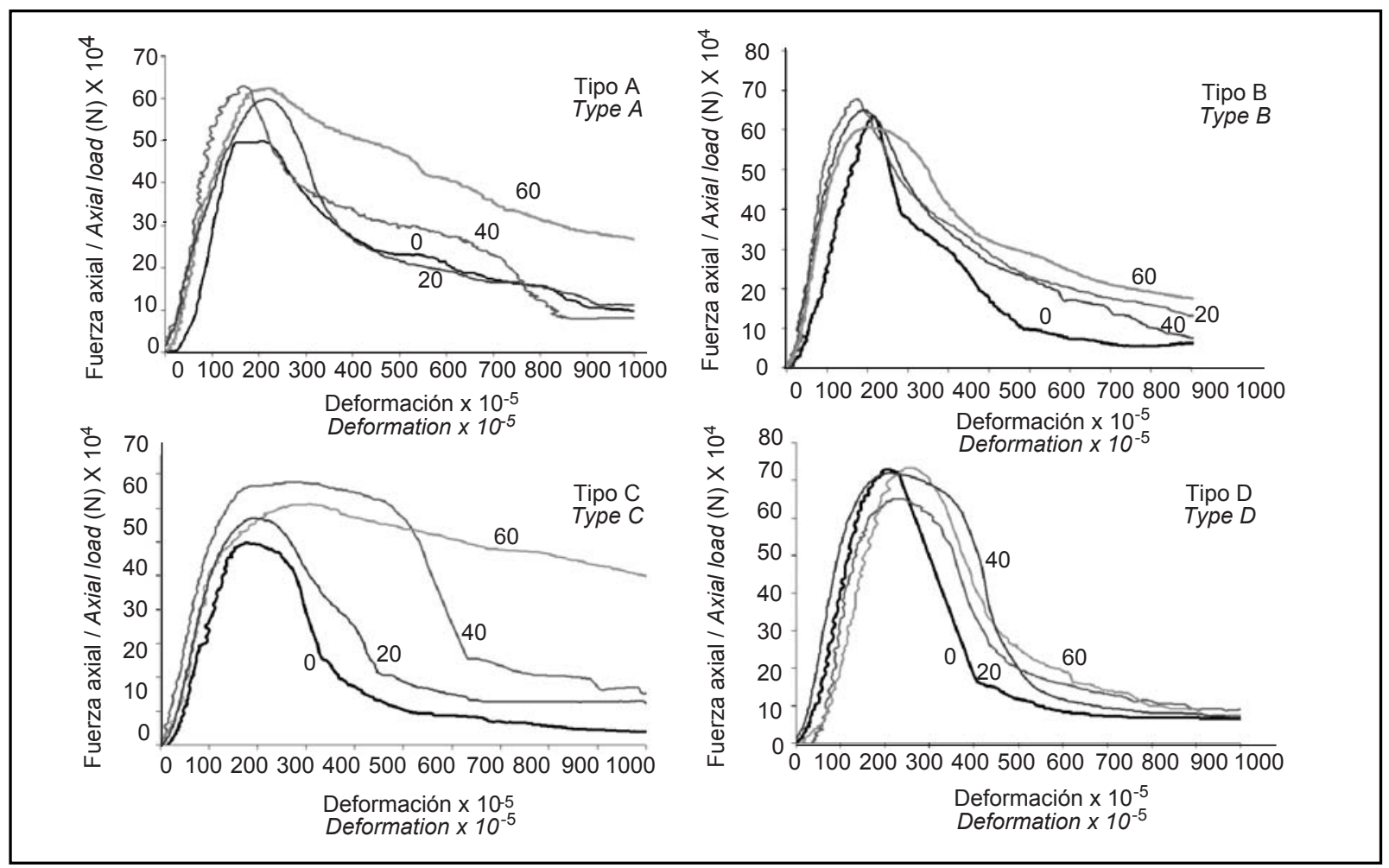

Figura 5. Curvas de fuerza axial - deformación unitaria de las probetas de tipo A, B, C y D.

Figure 5. Axial load - unit strain curves for specimen types A, B, C and D.

factores que limitan la capacidad resistente son, en el caso de la armadura, el límite elástico del acero $\left(f_{y} A_{s}\right)$, y en el del hormigón, su resistencia a la compresión ( $f_{c}$ $A_{c}$ ). Sin embargo, se ha demostrado en ensayos anteriores (19-20) que en general la resistencia a la compresión sólo alcanza el $85 \%$ de la observada en probetas cilíndricas. Dicha diferencia se justifica por el efecto dimensional y un moldeado más perfecto en el caso de estas últimas.

$$
\mathrm{N}_{\mathrm{O}}=0.85 \times \mathrm{f}_{\mathrm{c}} \times \mathrm{A}_{\mathrm{c}}+\mathrm{f}_{\mathrm{y}} \times \mathrm{A}_{\mathrm{S}}
$$

La Tabla 3 recoge la relación de las fuerzas axiales aplicadas en cada ensayo.

\section{ESTUDIO ANALÍTICO}

\subsection{Objetivos}

Según se ha indicado anteriormente, para calcular la ductilidad del sistema se necesita obtener para la estructura una curva de fuerza-desplazamiento ( $=$ de capacidad) en la que se incluyen todos los valores hasta alcanzar el que corresponde al del fallo teórico del sistema $\left(F_{85}\right)$. Dichos cálculos no pueden realizarse mediante el análisis elástico. Sin embargo, el análisis estático no lineal, concrete compressive strength ( $f_{c} A_{c}$ ). Tests (19-20) have long shown, however, that on average column compressive strength is only $85 \%$ of cylindrical compressive strength. The reasons for this difference are to be found in the size effect and the better results of form casting in cylindrical specimens.

The axial loads applied in each test are listed in Table 3.

\section{ANALYTICAL STUDY}

\subsection{Objectives}

As mentioned above, system ductility calculations require obtaining a load-displacement (capacity) curve for the frame up to and including the value corresponding to theoretical system failure $\left(F_{85}\right)$. Such calculations cannot be performed with elastic analysis. Pushover analysis, however, a recent and extremely useful method, can be used to find the sufficiency of structural strength 
un método reciente de gran interés, permite hallar la suficiencia de la resistencia mecánica de la estructura y el momento en que se alcanza el límite elástico, además de clasificar los elementos por orden cronológico de rotura.

Para esta parte, del estudio se desarrolló un modelo basado en una estructura de un solo vano en un edificio de dos plantas. Tanto la disposición de la armadura como la cuantía que se emplearon en dicho modelo eran las mismas que se utilizaron en las 16 probetas del experimento descrito en el apartado anterior. Se buscaba:

a) La ductilidad de la estructura basándose en las curvas de fuerza-desplazamiento halladas al realizar un análisis estático no lineal de las 16 estructuras.

b) La repercusión de la cuantía de fibra en la ductilidad, de acuerdo con los resultados del análisis.

\subsection{Procedimientos}

1. El modelo se desarrolló para un edificio de hormigón armado de dos plantas con un solo vano.

2. La sección de los pilares era de $160 \times 160 \mathrm{~mm}$ y la de las vigas de $160 \times 200 \mathrm{~mm}$. Es decir, la sección del pilar era igual a la de las probetas empleadas en el estudio experimental.

3. En los pilares, la cuantía de la armadura longitudinal era de $\rho_{1}=0,018$ (al igual que en el estudio experimental),

Tabla 3 / Table 3

Capacidades resistentes/cargas de rotura teóricas y experimentales

Theoretical and experimental load carrying capacities/ultimate loads

\begin{tabular}{|c|c|c|c|c|c|}
\hline $\begin{array}{l}\text { No de probeta } \\
\text { Specimen No }\end{array}$ & $\begin{array}{l}N_{o}(k N) \\
N_{o}(k N)\end{array}$ & $\begin{array}{l}N_{\mathrm{e}}(\mathbf{k N}) \\
N_{e}(k N)\end{array}$ & $\begin{array}{l}\mathbf{N}_{\mathrm{o}} / \mathbf{N}_{\mathbf{e}} \\
\mathbf{N}_{\delta} / \mathbf{N}_{e}\end{array}$ & 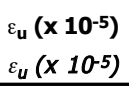 & $\begin{array}{l}\varepsilon^{{ }_{u}} / \varepsilon_{\text {su }}{ }^{\prime} \\
\varepsilon_{u} / \varepsilon^{{ }_{s u}}\end{array}$ \\
\hline $\mathrm{A} 1$ & 641 & 490 & 1.308 & 2650 & --- \\
\hline $\mathrm{A} 2$ & 640 & 600 & 1.066 & 3010 & 1.136 \\
\hline A3 & 642 & 625 & 1.027 & 3020 & 1.139 \\
\hline A4 & 631 & 610 & 1.034 & 3000 & 1.132 \\
\hline B1 & 629 & 620 & 1.014 & 3200 & --- \\
\hline B2 & 630 & 690 & 0.913 & 3400 & 1.063 \\
\hline B3 & 632 & 640 & 0.987 & 3700 & 1.156 \\
\hline B4 & 635 & 600 & 1.058 & 3500 & 1.094 \\
\hline $\mathrm{C} 1$ & 559 & 585 & 0.955 & 1800 & --- \\
\hline $\mathrm{C} 2$ & 559 & 630 & 0.887 & 1850 & 1.027 \\
\hline $\mathrm{C} 3$ & 559 & 800 & 0.698 & 1880 & 1.044 \\
\hline C4 & 580 & 705 & 0.822 & 2400 & 1.333 \\
\hline $\mathrm{D} 1$ & 557 & 720 & 0.774 & 1650 & --- \\
\hline D2 & 556 & 630 & 0.882 & 2700 & 1.636 \\
\hline D3 & 558 & 715 & 0.780 & 2720 & 1,648 \\
\hline D4 & 545 & 730 & 0.746 & 2200 & 1.333 \\
\hline
\end{tabular}

and yield times and rank members by order and order of failure.

A reinforced concrete single span frame for a two-storey building was modelled for this part of the study. The column reinforcement design and fibre ratios used in this model were the same as in the above 16-column experiment. The information sought included:

a) frame ductility based on the load-displacement curves found by conducting non-linear static analysis on 16 frames.

b) the effect of the fibre ratio on ductility, according to analytical findings.

\subsection{Procedures}

1. The model was developed for a single-span, two-storey $R C$ building.

2. Column and beam cross-sections measured $160 \times 160$ $\mathrm{mm}$ and $160 \times 200 \mathrm{~mm}$, respectively. In other words, the column section was the same as in the specimens used for the experimental study.

3. The longitudinal reinforcement ratio was $\rho_{1}=0.018$ in columns (as in the experimental study) and $\rho_{b}=0.007$

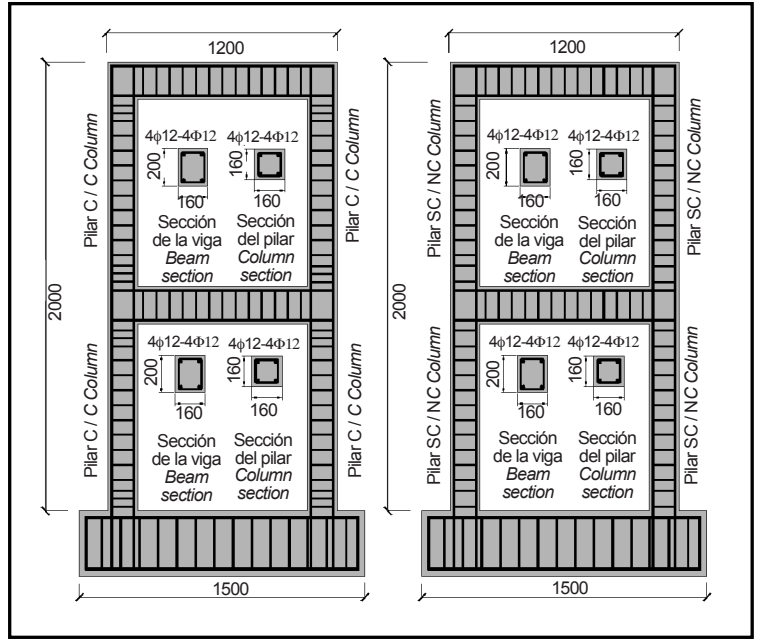

Figura 6. Disposición de la armadura de la estructura. Figure 6. Reinforced concrete frame geometry. 
siendo de $\rho_{b}=0,007$ en las vigas. (La norma turca TEC-98 exige que la cuantía de armadura longitudinal en pilares sea de al menos el $1 \%$ y que la de la armadura de tracción de las vigas, tanto en el tramo central como sobre los apoyos, no supere el $2 \%$.)

4. En la Figura 6, con los símbolos $\Phi$ y $\phi$ se representan las armaduras, cuyo límite elástico es de $440 \mathrm{MPa}$ y $268 \mathrm{MPa}$, respectivamente. La geometría de la estructura queda recogida asimismo en la Figura 6.

5. Se realizaron los cálculos con la ayuda de un programa informático, concretamente el Drain-2D (21).

Según se ha visto anteriormente, el análisis estático no lineal se llevó a cabo para trazar la curva de fuerza lateral - desplazamiento de las estructuras, con vistas a relacionar su comportamiento con la ductilidad del sistema y a localizar las rótulas plásticas (22-24).

Las rótulas plásticas de los pilares, los puntos más críticos del sistema, modifican el comportamiento de éste drásticamente y aumentan su periodo al reducir la pendiente de la curva fuerza-desplazamiento. (Rigidez $\alpha=\frac{1}{\text { period }}$ donde $\alpha$ representa grados de libertad.)

En estos cálculos, se han adoptado para la resistencia del hormigón y el límite elástico los valores reseñados en la Tabla 1. En el programa informático utilizado, la fuerza perpendicular se ha aplicado controlando la presión ejercida, mientras que la horizontal se ha aplicado controlando el desplazamiento. La disposición de las fuerzas aplicadas puede apreciarse en el esquema a la izquierda de la Figura 7. in beams. (TEC-98 specifies a minimum longitudinal column reinforcement ratio of $1 \%$ and a maximum $2 \%$ ratio for the tensile reinforcement along beam spans and at supports.)

4. In Figure 6, the symbols $\Phi$ and $\phi$ represent reinforcing steel with yield strength values of $440 \mathrm{MPa}$ and 268 $\mathrm{MPa}$, respectively. Frame geometry is also shown in Figure 6.

5. Drain-2D (21) software was used to perform the calculations.

As noted earlier, pushover analysis was conducted to determine the lateral load - displacement curve for the frames, with a view to relating frame behaviour to system ductility and ascertaining plastic hinge location (22-24).

The plastic hinges on the columns, the most critical points in the system, change system behaviour drastically and increase its period by flattening the load-displacement curve. (Stiffness $\alpha=\frac{1}{\text { period }}$ where $\alpha$ is degrees of
freedom.)

The concrete and yield strength assumed for each member in these calculations were taken from Table 1. In this software, the loading pattern is formed with a load-controlled normal force and a displacement-controlled horizontal force. The pattern of forces applied to the frame is depicted in the drawing on the left in Figure 7.

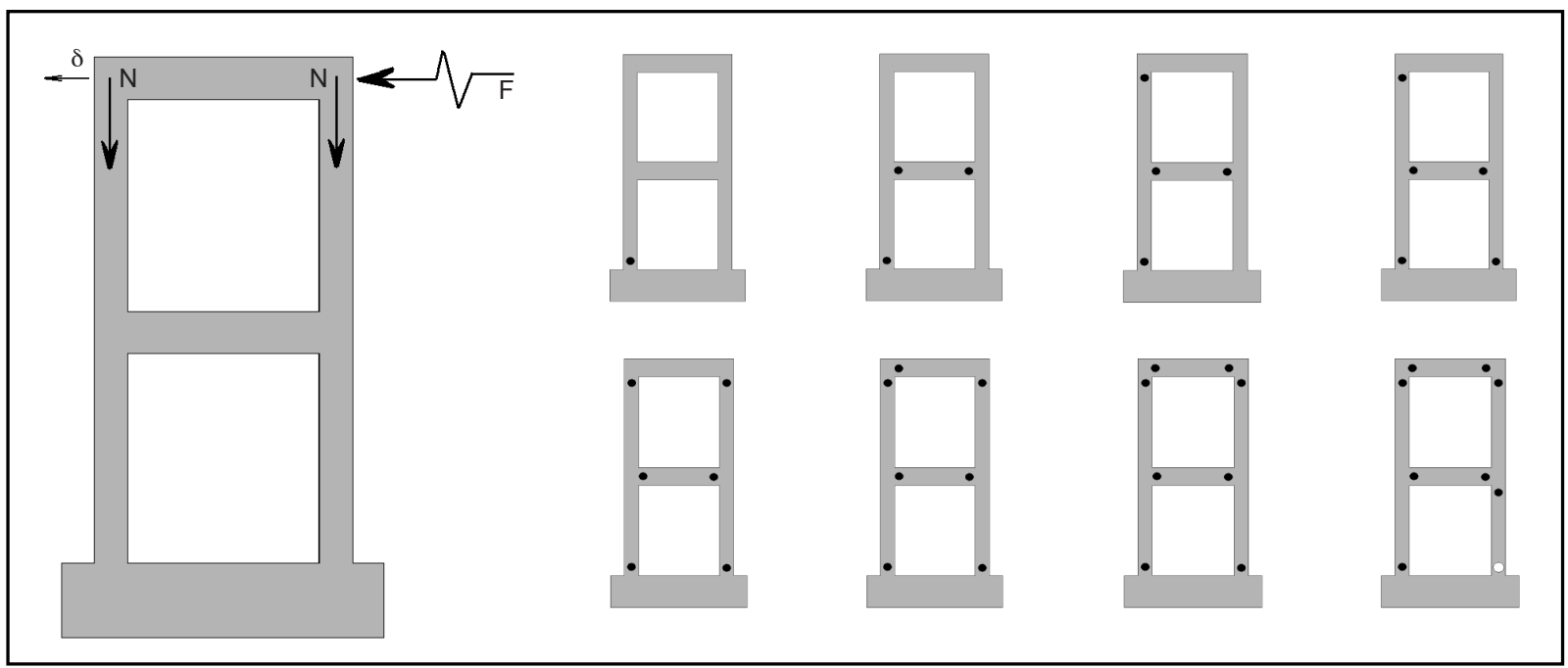

Figura 7. Fuerzas aplicadas a la estructura y formación de las rótulas plásticas. Figure 7. Frame loading pattern and formation of plastic hinges. 


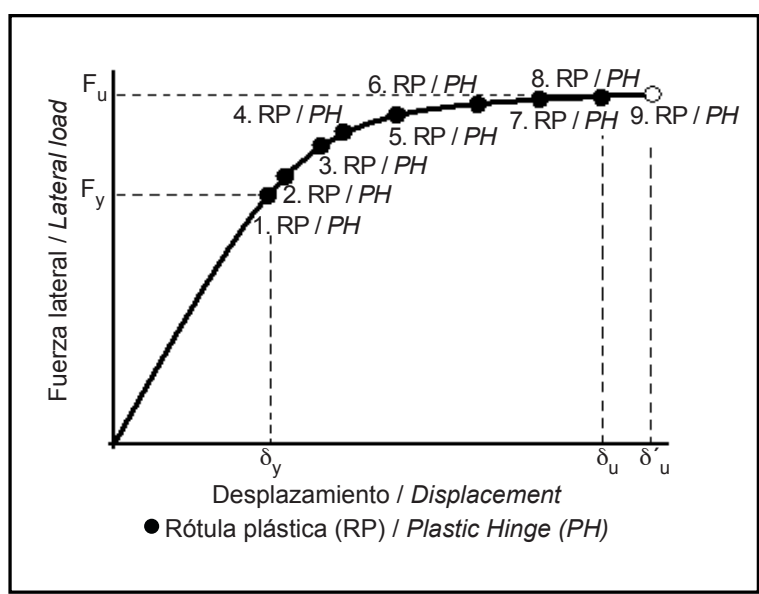

Figura 8. Curvas de fuerza-desplazamiento de las estructuras, con indicación de los puntos de formación de las rótulas plásticas. Figure 8. Load-displacement curves for frames showing points where plastic hinges appeared.

\subsection{Evaluación}

El orden y la situación de las rótulas formadas se muestran en la Figura 7. Aunque las rótulas aparecieron en el mismo orden y en los mismos puntos en las 16 estructuras, sus niveles de tensión-deformación variaban. La rótula aparecida en último lugar, representada en color blanco en la parte inferior derecha del esquema, sólo se detectó en las probetas tipo $C$ y $D$. La curva de fuerza-desplazamiento se recoge de forma idealizada en la Figura 8 . En la figura, $F_{u}$ y $F_{y}$ son los valores de fuerza que corresponden al desplazamiento de la estructura en el momento de rotura y al alcanzar el límite elástico, respectivamente. Por otra parte, el valor de desplazamiento de rotura de los tipos $A$ y $B, \delta_{u}$ era menor que el valor observado para los tipos $C$ y $D, \delta_{u}{ }^{\prime}$. En la Figura 9 se recogen las curvas de fuerza-desplazamiento correspondientes a los cuatro tipos de estructura, A, $B, C$ y $D$.

\subsection{Cálculo de la ductilidad de la estructura (sistema)}

Queda patente, del examen de la expresión empleada para calcular la ductilidad de la estructura (el sistema), que desempeña un papel esencial la relación entre el desplazamiento en el momento de empezar a alcanzarse el límite elástico y el que corresponde a la rotura. Resulta fácil identificar el desplazamiento de rotura en las curvas de fuerzadesplazamiento. Al no descender la curva después de alcanzarse la carga máxima, se ha adoptado como valor del desplazamiento de rotura el del desplazamiento observado en el punto de carga lateral máxima, en vez de en el punto $\delta_{85}$. Para el desplazamiento en el límite elástico se adoptó el valor $\delta_{75}$ (el que corresponde al $75 \%$ de la fuerza lateral que puede soportar la estructura). La Tabla 4 recoge los valores de ductilidad que corresponden a los de desplazamiento en el límite elástico y en el momento de la rotura.

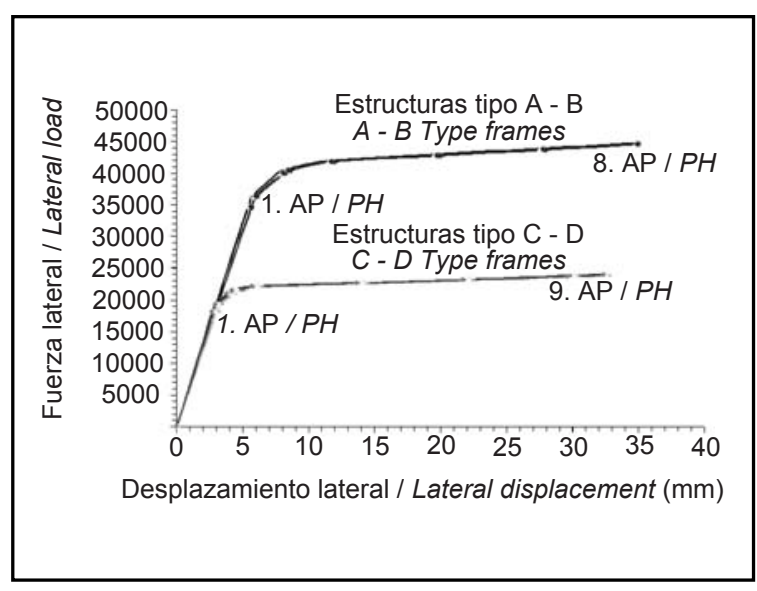

Figura 9. Curvas de fuerza-desplazamiento de todas las estructuras.

Figure 9. Load-displacement curves for all frames.

\subsection{Evaluation}

The order and location of hinge formation are shown in Figure 7. Although the order of appearance and location of the plastic hinges were the same in all 16 frames, their stress-strain levels differed. The last hinge to appear in the drawing, shown in white on the lower right, was detected in specimen types $C$ and $D$ only. The load-displacement curve is shown schematically in Figure 8. In the figure, the $F_{u}$ and $F_{y}$ loads are respectively responding to the ultimate and yield displacements. While the ultimate displacement value for specimen types $A$ and $B$ was $\delta_{u}$, a higher value, $\delta_{u}{ }^{\prime}$, was found for types $C$ and $D$. The load-displacement curves are shown separately for frames $A, B, C$ and $D$ in the graphs in Figure 9.

\subsection{Calculation of frame (system) ductility}

As may be inferred from the formula for calculating frame (system) ductility, the ratio between initial yield displacement and ultimate displacement is essential. Ultimate displacement is readily identified on load-displacement curves. Since no decrease was observed on the curve after the maximum load was reached, ultimate displacement was assumed to be the displacement at the maximum lateral force, instead of at $\delta_{85}$. Yield displacement was accepted to be $\delta_{75}$ (displacement under the load corresponding to $75 \%$ of the lateral force that can be carried by the frame). The ductility values corresponding to the yield and ultimate displacement values for the frame are given in Table 4. 
Tabla 4 / Table 4

Ductilidad de la estructura

Frame ductility

\begin{tabular}{|c|c|c|c|c|c|c|c|}
\hline $\begin{array}{l}\text { Tipo de estructura } \\
\text { Specimen }\end{array}$ & $\begin{array}{l}\text { Grupo de estructura } \\
\text { Frame group }\end{array}$ & $\begin{array}{l}\mathbf{f}_{c}(\mathrm{MPa}) \\
f_{c}(\mathrm{MPa})\end{array}$ & $\begin{array}{l}f_{y}(M P a) \\
f_{y}(M P a)\end{array}$ & $\begin{array}{c}\text { Cuantía de fibra }\left(\mathbf{k g} / \mathrm{m}^{3}\right) \\
\text { Fibre ratio } \mathrm{kg} / \mathrm{m}^{3}\end{array}$ & $\begin{array}{l}\delta_{\mathbf{y}}=\delta_{85}(\mathrm{~mm}) \\
\delta_{y}=\delta_{85}(\mathrm{~mm})\end{array}$ & $\begin{array}{l}\delta_{\mathbf{u}}(\mathbf{m m}) \\
\delta_{u}(\mathrm{~mm})\end{array}$ & $\begin{array}{l}\mu \delta \\
\mu \delta\end{array}$ \\
\hline $\mathrm{A} 1$ & 2 & 20.35 & 440 & 0 & 5.850 & 35.150 & 6.009 \\
\hline $\mathrm{A} 2$ & 2 & 19.80 & 440 & 20 & 5.843 & 35.310 & 6.043 \\
\hline A3 & 2 & 20.16 & 440 & 40 & 5.826 & 35.750 & 6.136 \\
\hline A4 & 2 & 20.05 & 440 & 60 & 5.815 & 35.840 & 6.163 \\
\hline B1 & 1 & 20.27 & 440 & 0 & 5.048 & 34.973 & 6.927 \\
\hline B2 & 1 & 19.85 & 440 & 20 & 4.922 & 34.893 & 7.089 \\
\hline B3 & 1 & 20.13 & 440 & 40 & 4.938 & 34.897 & 7.067 \\
\hline B4 & 1 & 20.00 & 440 & 60 & 4.864 & 34.871 & 7.168 \\
\hline $\mathrm{C} 1$ & 2 & 20.36 & 268 & 0 & 2.910 & 32.500 & 11.168 \\
\hline $\mathrm{C} 2$ & 2 & 19.91 & 268 & 20 & 2.915 & 32.870 & 11.276 \\
\hline $\mathrm{C} 3$ & 2 & 20.15 & 268 & 40 & 2.911 & 32.980 & 11.329 \\
\hline C4 & 2 & 20.10 & 268 & 60 & 2.913 & 33.450 & 11.483 \\
\hline D1 & 1 & 19.87 & 268 & 0 & 2.943 & 32.568 & 11.066 \\
\hline D2 & 1 & 20.03 & 268 & 20 & 2.901 & 32.442 & 11.184 \\
\hline D3 & 1 & 21.12 & 268 & 40 & 2.745 & 32.322 & 11.771 \\
\hline D4 & 1 & 19.50 & 268 & 60 & 2.666 & 32.303 & 12.114 \\
\hline
\end{tabular}

\section{RESULTADOS Y DISCUSIÓN}

Los resultados obtenidos en el presente estudio experimental y analítico se resumen a continuación:

1. Independientemente del aumento de la ductilidad tras la incorporación de la fibra de acero al hormigón, la resistencia a la compresión no se incrementó de manera significativa en ninguna de las probetas ensayadas.

2. El comportamiento de las probetas en la rotura, en cambio, sí se vio afectado por la presencia de las fibras de acero. Mientras que las que estaban exentas de fibra se rompieron por fallo frágil, acompañado de estallido intenso del hormigón, las que estaban reforzadas tuvieron un comportamiento más dúctil.

3. El estudio analítico ha demostrado que la presencia de fibra de acero de refuerzo aumentaba de manera efectiva la ductilidad de la estructura. En los cuatro tipos de elementos, la ductilidad ascendió entre un 2,6 y un $9,4 \%$, en función de la cuantía de fibra que se había incorporado. Éste es un resultado importante para las zonas sísmicas, donde se exigen valores altos de ductilidad.

4. La ductilidad aumentó en mayor proporción en las estructuras de tipo $D$, que contenían una cuantía mayor de armadura de confinamiento y en las que el acero empleado tenía un límite elástico menor.

5. La carga de rotura no dependía de la cuantía de fibra, siendo igual en las estructuras con y sin dicho refuerzo. Así, las fibras parecen incidir poco o nada en la formación de las rótulas plásticas.

\section{RESULTS AND DISCUSSION}

The results obtained from the present experimental research and related analytical study are as follows:

1. Irrespective of whether ductility increased with the inclusion of different ratios of steel fibres in the concrete, no significant rise in compressive strength was observed.

2. The presence of steel fibres did affect specimen failure patterns, however. Samples with no fibre exhibited brittle failure and severe concrete spilling. The behaviour of the steel fibre-reinforced specimens, by contrast, was more ductile.

3. The analytical study showed that steel fibre reinforcement contributes effectively to frame ductility. In the four types of members, ductility rose by 2.6 to $9.4 \%$, depending on the ratio of fibre added. This is an important feature in seismic zones where high ductility is imperative.

4. Ductility rose more in frames with a higher proportion of confinement reinforcement and a lower steel yield strength (type D).

5. The ultimate load in steel fibre-reinforced frames, which was independent of the fibre ratio, was the same as in non-fibre reinforced frames. Hence the fibres appear to have little to no effect on the materialization of plastic hinges. 
6. La situación y orden de aparición de dichas rótulas eran iguales dentro de cada subgrupo. Es decir, la presencia o ausencia de fibra no influyó en la formación de las mismas. Aunque las estructuras tipo A y B fallaron al formarse la octava rótula, en los tipos $C$ y $D$ la rotura no se produjo hasta que la formación de la novena.

7. Las curvas de capacidad obtenidas mediante el análisis estático no lineal mostraron que el comportamiento de la estructura era muy similar en los distintos sistemas, independientemente de la cuantía de fibra de acero incorporada. De hecho, al determinar la carga de rotura, se observó que el parámetro que más incidía en el valor final era el límite elástico del acero de la armadura. La capacidad resistente demostró ser independiente de la resistencia a la compresión del hormigón empleado, la presencia o ausencia de armadura de confinamiento y la cuantía de la fibra de acero.

En la edificación sismorresistente, la ductilidad es la consideración más importante a nivel de proyecto. Puede evitarse el hundimiento total si las estructuras tienen la ductilidad suficiente para absorber la energía sísmica. Toda la normativa vigente sobre edificación en zonas sísmicas recoge las exigencias básicas de ductilidad de los materiales y los elementos estructurales. El presente trabajo demuestra claramente que las fibras de acero aumentan la ductilidad de las estructuras (Figura 10). Los efectos de las fibras de acero (o similar) sobre la ductilidad deberán tenerse en cuenta en las eventuales modificaciones futuras de dicha normativa.

\section{AGRADECIMIENTOS}

Los autores agradecen al Comité de Investigación de la Universidad de Selcuk el apoyo prestado en relación con el presente trabajo, dando asimismo las gracias al Comité S.U. - BAP y a TUBITAK-BAYG por la ayuda financiera.
6. Hinge locations and order of appearance were the same in each group of four specimens. In other words, the fibres had no impact on this development. While frame types $A$ and $B$ failed with the appearance of the eighth hinge, types $C$ and $D$ failed after the ninth.

7. The capacity curves obtained with non-linear static analysis revealed that frame behaviour was fairly similar in systems with different ratios of steel fibre. The predominant parameter in the determination of the ultimate load was, in fact, reinforcement yield strength. Frame carrying capacity was essentially unaffected by the compressive strength of the concrete used, the existence or otherwise of confinement or the steel fibre ratio.

Ductility is the key property in earthquake-resistant building design. Total collapse can be prevented if structures are ductile enough to absorb seismic energy. All existing building codes for seismic areas stipulate the basic ductility requirements for structural members and materials. This study clearly shows that steel fibres enhance frame ductility (see Figure 10). Future amendments to such codes should take account of the effects of steel (or similar) fibres on ductility.

\section{ACKNOWLEDGEMENTS}

Funding for this study was provided by the Selcuk University Research Committee, the S.U. - BAP Committee and TUBITAK-BAYG.

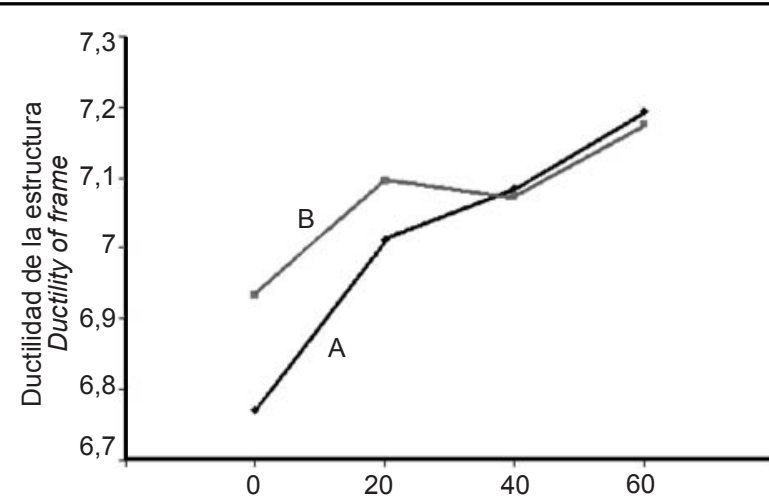

Cuantía de fibra de acero / Amount of steel fibre $\left(\mathrm{kg} / \mathrm{m}^{3}\right)$

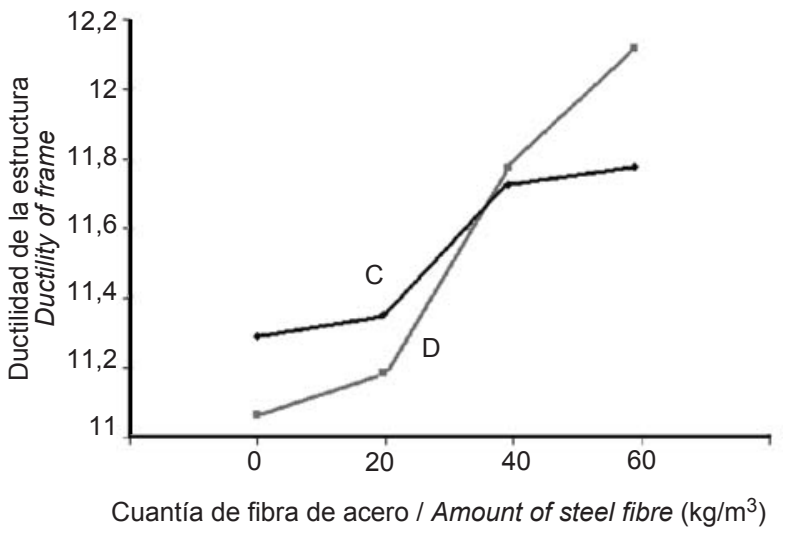

Cuantía de fibra de acero / Amount of steel fibre $\left(\mathrm{kg} / \mathrm{m}^{3}\right)$

Figura 10. Ductilidad de la estructura en función de la cuantía de fibra de acero.

Figure 10. Steel fibre ratio vs frame ductility. 


\section{BIBLIOGRAFÍA / BIBLIOGRAPHY}

(1) Sukontasukkul P.; Mindess S.; Banthi N.: "Properties of confined fibre-reinforced concrete under uniaxial compressive impact", Cement \& Concrete Research, 35 (1) (2005), pp. 11-18.

(2) Oh, B. H.; Park, D. G.; Kim, J. C.; Choi Y. C.: "Experimental and theoretical investigation on the post-cracking inelastic behavior of synthetic fiber reinforced concrete beams", Cement \& Concrete Research, 35 (2) (2005), pp. 384-392.

(3) Song, P. S.; Hwang, S.: "Mechanical properties of high-strength steel reinforced concrete", Construction and Building Materials, 18

(9) (2004), pp. 669-673.

(4) Rao G.; Seshu, R.: "Torsion of steel fiber reinforced concrete members", Cement \& Concrete Research, 33 (11) (2003), pp. 17831788.

(5) Ayers, S. R.; Van Erp, G. M.: "A code of practice for the structural design of fibre composites" PIC Structures and Buildings, 157 (2003), pp. 3-8.

(6) Ramesh, K.; Seshu, D. R.; Prabhakar, M.: "Constitutive behavior of confined fibre reinforced concrete under axial compression", Cement \& Concrete Composites, 25 (2003), pp. 343-350.

(7) Craig, R. J.; Patel, C.: "Behavior of joints using reinforced fibrous concrete", Fibre Reinforced Concrete International Symposium, American Concrete Institute, Detroit, 1989.

(8) Sheikh, A. S.: "A comparative study of confinement models", ACI J. Mater., 79 (04) (1982), pp. 296-306.

(9) Shah, S. P.; Rangan, B. V.: "Effects of reinforcements on ductility of concrete", Proceeding ASCE, 96 (576) (1970), pp. 1167-1184.

(10) Gioncu, V.: "Framed structures. Ductility and seismic response, General Report", Journal of Constructional Steel Research, 55 (2000), pp. 125-154.

(11) Kappos, A. J.; Chryssanthopoulos, M. K.; Dymiotis, C.: "Uncertainty analysis of strength and ductility of confined reinforced concrete members", Engineering Structures, 21 (1999), pp. 195-208.

(12) Lu, Y.; Hao, H.; Carydis, P. G.; Mouzakis, H.: "Seismic performance of RC frames designed for three different ductility levels", Engineering Structures, 23 (2001), pp. 537-547.

(13) Regulations on Structures constructed in Disaster Regions (TEC-98), Ministry Of Public Works and Settlement, Ankara, 1998.

(14) UBC-97 Uniform Building Code, International Conference of Buildings Official, USA, 1997.

(15) Eurocode-8-98 Design Provisions for Earthquake Resistance of Structures, European Union, European Prestandarts, Brussel, 1998.

(16) Borzi, B.; Elnashai, A. S.: "Refined Force Reduction Factor for Seismic Design", Engineering Structures, 2000, pp. 1244-1260.

(17) Kappos, A. J.: "Evaluation of Behaviour Factor on the Basis of Ductility and Overstrength Studies", Engineering Structures, 1999, pp. 823-835.

(18) TBC-500-2000, Turkish Building Code, Requirements For Design and Construction of Reinforced Concrete Structures, 2000.

(19) Richart, F. E.; Staehle, G. C.: "Column Tests at University of Illinois", Journal of ACI, febrero-marzo de 1931, noviembre de 1931 y enero de 1932

(20) Slater, W. A.; Lyse, I.: "Column Tests at Lehigh University", Journal of ACI, marzo de 1931, noviembre de 1931 y enero de 1932. (21) Prakash, V.; Powell, G. H.; Campbell, S.: Drain-2dx User Guide V.1.10, Departmant of Civil Engineering, University of California at Berkeley, 1993.

(22) Mwafy, A. M.; Elnashai, A. S.: "Calibration of Force Reduction Factors of RC Buildings", Journal of Earthquake Engineering, vol. 6, n० 2 (2002), pp. 239-273.

(23) Mwafy, A. M.; Elnashai, A. S.: "Static Pushover Versus Dynamic Collapse Analysis of RC Buildings", Engineering Structures, 2001, pp. 407-424.

(24) Paulay, T.; Priestly, M. J. N.: "Seismic Design of Reinforced Concrete and Masonry Buildings", Concrete \& Cement Composites, John Wiley \& Sons Interscience Publication, Nueva York, 1992. 